\title{
The Constraints Of Management Of Zakat And Its Potentials In Poverty Reduction (Case Study Medan City)
}

\author{
Siti Mujiatun \\ University of Muhammadiyah Sumatera Utara, \\ Medan, North Sumatera, Indonesia
}

\begin{abstract}
This study aims to reveal the potential of zakat that has not been managed optimally, especially in the city of Medan. The government such as issuing laws on the management of zakat and establishing a formal institution in order to collect and channel zakat society has made various efforts more efficiently. Currently management efforts, especially zakat profession has shown results in reducing poverty even though not optimal. Various obstacles still exist so that necessary evaluation and strategic steps for the management of zakat to be better in the future.
\end{abstract}

Keywords: Zakat Potential, Zakat Management, and Poverty.

\section{INTRODUCTION}

Islam is the largest religion of adherents in Indonesia. According to statistics, the growth of Indonesian Muslims was initially quite encouraging. According to the 1990 population census, the number of Muslims reached 87.6 percent. This number then increased to 88.2 percent according to the 2000 population census. The annual growth rate of Muslims today is only 1.2 percent, while the growth rate of Christians is twice that of 2.4 percent per year. According to other sources the development of Muslims is very small, which in the beginning was quite encouraging. Its growth continued to fall from $95 \%$, to $92 \%$, and down again to $90 \%$, then to $87 \%$ and $85 \%$ today.

Apart from the decline in the number of Muslims in Indonesia Muslims can still believe in aqidah in accordance with existing guidance, perform worship and muamalah. Zakat that is an integral part of Islamic teachings has legal basis in Indonesia with the issuance of Law number 23 of 2011 on the management of zakat.

Zakat is a potential source of funds that can be utilized for the general welfare of the entire community. In addition, zakat can also to alleviate poverty and eliminate social inequality. In order to achieve maximum results, zakat needs to be managed professionally and responsibly. This should be done simultaneously between the community and the government. The government is obliged to provide protection, guidance and service to muzakki, mustahiq and zakat managers. The aim is to provide awareness to the community in implementing the obligation to pay zakat, service and management by the zakat collector (Amil) of Zakat Agency. Thus, zakat is expected to be truly capable of realizing the welfare of society and social justice, as well as the increased use and utilization of zakat.

\section{THEORITICAL FRAMEWORK}

The amount of potential and realization of zakat as a solution to poverty alleviation is still considered one eye, whereas the majority Muslim population has a huge potential of zakat. In general, zakat potential in Indonesia is still within the range of high zakat potential according 
to Kahf's calculations (1989). Kahf (1989) stated that the potential of zakat in Islamic countries around the world is about 1.8-4.34\% of total GDP. The estimation of the potential of zakat in Indonesia has been done by various circles, for example, Firdaus et al (2012) divides the potential of zakat into three groups: individual zakat potential (household), zakat potential of companies / industries, and zakat potential of deposits in private banks or government public banks and deposits.

The main purpose of zakat is the enrichment of the poor and the elevation of their status from the recipient of zakat to the giver of zakat. In principle, zakat should be given as a direct transfer payment to the poor. This revenue redistribution aims in addition to increasing the income of the poor and available capital, but also enhances their ability to make responsible decisions about the use of their income. Ahmed (2004) argues that the result of zakat should be enough to effectively distribute wealth and income.

Ahmad (2008) says why zakat has not had effective benefits in the past? The main reason is that Muslims at that time still paid their zakat traditionally directly and personally. They have not understood and instilled the values of the need for zakat to be channeled through the institution. However, in line with the dynamics of the activities of zakat management organizations have had an impact on the change of zakat behavior of Indonesian society. If in 1997 the people who paid their zakat through formal institutions were less than 3\%, while by the end of 2006 the coverage was almost 20\% (Ahmad, 2008).

Beik (2011) argues that zakat can play a very significant role in redistributing income and wealth in Muslim societies. In his study, Pramanik (1993) states that in the macroeconomic context, zakat can serve as an instrument that can provide incentives to increase production and investment.

Next Beik (2011). He stated that the alocative function of zakat is expressed as a tool or instrument to combat poverty. However, in the pattern of distribution, zakat is not only given in the form of consumer goods but also in the form of production goods. This is done when mustahik has the capacity and ability to process and perform production activities. He also encourages the distribution of zakat in the form of equity, which is expected to give a broader impact on economic conditions.

El-Din (1986) tries to analyze the allocative functions and zakat stabilizers in the economy. He stated that the alocative function of zakat is expressed as a tool or instrument to combat poverty. However, it should be in the pattern of distribution, zakat is not only given in the form of consumer goods but also in the form of production goods. This is done when mustahik has the capacity and ability to process and perform production activities. He also encourages the distribution of zakat in the form of equity, which is expected to give a broader impact on economic conditions.

Pramanik (1993) argues that zakat can play a very significant role in redistributing income and wealth in Muslim societies. In his study, Pramanik (1993) states that in the macroeconomic context, zakat can serve as an instrument that can provide incentives to increase production, investment, and to work. Zakat is the best transfer mechanism in society.

A number of studies to see empirically the impact of zakat on poverty reduction and unemployment have been done, although it is still limited. Jehle (1994) tried to analyze the impact of zakat on gaps and inequities that occurred in Pakistan. 
Using the AKS Gap Index (Atkinson, Kolm and Sen), Jehle (1994) was able to construct two types of income using 1987-1988 data, namely: income data without zakat and income data involving zakat. He found that zakat was able to drain income from the middle group to the lower group, although in very small amounts.

Patmawati (2006) tries to analyze the role of zakat in reducing poverty and income gaps in Selangor state, Malaysia. Using the Lorenz curve and Gini coefficients, he found that the bottom 10 percent of people enjoy 10 percent of the people's wealth due to zakat. This number increased from 0.4 percent when zakat transfer did not occur. While the top 10 percent of the community enjoys a fortune of 32 percent, or down from 35.97 percent in the previous position. This shows that the gap between groups can be reduced. He also concluded that zakat can reduce the number of poor families, reduce the depth and severity of poverty in Selangor.

Next Shirazi (2006) tries to analyze the impact of zakat and 'ushr on poverty alleviation efforts in Pakistan. Using FGT (Foster, Greer and Thorbecke) Index, he found that in 1990-1991, 38 percent of households in Pakistan lived below the poverty line. But the figure would be 38.7 percent if the zakat transfer mechanism did not occur. He also concluded that the poverty gap decreased from 11.2 percent to 8 percent with the presence of a voluntary zakat transfer mechanism.

From the various studies that can be concluded that it is necessary to maximize efforts in collecting and distributing zakat productively. Because Kahf (1989) reminded that the distribution of zakat will never be able to alleviate poverty if the amount of zakat is still small. Discourse on zakat as a tool for poverty alleviation cannot avoid the question of how to expand the base of zakat so that the amount of zakat to be divided into larger.

\section{RESULT AND DISCUSSION}

The amount of potential zakat profession in the city of Medan and has not been explored to the maximum should be a concern. Especially the big agenda faced by this nation is the problem of poverty. The higher the rate of poverty is also increasing social gap that is sure to create various social problems, let alone the majority of Muslims. This is due to factors ranging from lack of opportunity, low opportunity, lack of assurance and helplessness. Therefore, poverty with all its dimensions is a crucial issue that must be completed and become a major agenda with various government programs and participation of all elements of society

If we see, the government's efforts in poverty eradication, require resources that are not the least of both human and material resources. The government has created poverty alleviation programs and allocates substantial amount of funds formulated annually in APBN, but it has not been said maximally. With the potential of reaching 3.40\% of GDP or not less than Rp 217 trillion annually, then the existence of zakat must be optimized in the collection and distribution.

Zakat with maximum collection can be used as an instrument of poverty alleviation. As the purpose of zakat management itself is: Increased service for the community in the fulfillment of zakat in accordance with religious guidance. Increasing the function and role of religious institutions in the effort to realize the welfare of society and social justice.

Although the reality shows so many obstacles becomes an important issue for the government and the private sector in collecting, managing and distributing zakat profession for poverty alleviation in the city of Medan. There are several factors that become obstacles as zakat 
institutions in managing zakat profession, in this paper divided by two there are special factors and there are common factors. The specific constraints are as follows:

1. The companion of the business who is occupied by the recipient of zakat funds profession. It turned out that many of his companions who moved out of town, both as civil servants and entrepreneurs, so that businesses that had been advanced to be hampered progress.

2. Regular news collection and distribution of zakat profession at Bank Muamalah ever made, but the archive borrowed by others and not returned.

3. For the Institute of Amil Zakat PT Bank of North Sumatra, the perceived obstacle is mainly related to the zalcat distribution productively that mustahik in managing zakat profession less trust.

4. Obstacles felt by the manager of zakat profession shows some participants of zakat (muzakki) who want to withdraw their funds because they want to distribute themselves, but before the gathering has conveyed the subject.

The common constraints felt by zakat institutions are the common problems that occur in the community, namely:

1. Lack of Institutional Talent Awareness: Lack of zakat awareness to the institution becomes an important issue in collecting, managing and distributing zakat profession. Not all employees give their professional charity to the institution. Whereas with zakat talent provides strategic value that is: First, increase the amount of collection of zakat institutions concerned. Second, the collected zakat funds are managed and distributed in an appropriate and appropriate manner. Thirdly, the zakat paid to the institution is evenly distributed on the basis of justice and equity of zakat asnaf. Fourth, the muzakki paying zakat to the institution will be spared from riya muzakki. If zakat paid directly affects psychology mustahik, because he knows that the aid of zakat comes from the muzakki he knows.

2. The absence of Muzakki punishment: The existence of sanctions becomes an imperative force in the management of zakat. However, Law No. 23/2011 on Zakat Management in Indonesia also does not strictly regulate to muzakki. Although a person is able to pay zakat, but the absence of sanctions does not become a strong motive muzakki pay zakat to the institution. It also has implications for government and private zakat institutions in Medan city

3. Lack of Socialization: Lack of socialization also becomes a challenge in collecting, managing and distributing zakat profession. Moreover, socialization becomes an important engine in encouraging tillage. The program of socialization and communication is also no less important in the collection of zakat funds. For some people are still many who do not know about prison. Not knowing things related to the law of prison, not understanding the role of ZIS and the importance of paying zakat through the institution. Suppose some people know that the society is thicker to practice the old values by paying directly to pay zakat, that is, the people prefer to understand the zakat law as it grows in society and it has been for a long time. Some think this condition cannot be separated from the role of religious elites and others who more often motivate the worship of Muslims to perform worship, fasting, pilgrimage rather than zakat. But at the same time, it must be admitted that among the religious elites who convey the message of zakat can be said to be still narrow in the sense only zakat fitrah and zakat mal as written in the books of classical fiqh only. Even if one discusses zakat, usually only seen from the point of law only. This can be seen from the dialogues that there are more questions about the law, such as how the law of zakat given directly by muzakki, little found the public view in a sense of comprehensive view of the dimension of bias on the social issues of humanity. Given the dominance of this 
legal perspective, it causes little room for interpreting zakat. As the understanding that legal perspective is an absolute black and white perspective, causing narrow space of interpretation for some Islamic thinkers to perform ijtihad steps on zakat, for example renewal of zakat object to segment of zakat potential as effect of economic development of society. Some socialization steps that must be done by the zakat institution in building zakat knowledge to the community: First, establish cooperation. Secondly, technically with other institutions / agencies in terms of counseling and accumulation of Zakat, Infaq and Sadaqah (ZIS). Third, Conduct coordination, integration and synchronization of a technical nature (not wisdom) with all parties to the collection of Zakat, Infaq and Sadaqah (ZIS) is more optimal. Fourth, Conducting cooperation with similar professional institutions as partners or synergies in extension of Zakat, Infaq and Sadaqah (ZIS).

4. Khilafiyah in Society: Khilafiyah in the community remains popular about the sources of zakat and mustahik zakat. This difference of opinion begins when the Qur'an unravels in tafshiliyah the sources of zakat property consisting of zakat livestock, gold and silver, trade treasures, plant yields, minerals and inventions, then the dynamics of zakat law will become rigid, Islam will stop here. But the Qur'an also speaks differently, while understanding the zakat not only through the tafshiliyah approach, but also using the general approach (ijmal). Implicit various potential sources of zakat with economic value that must be put into law. According to Yusuf Qaradawi the arguments against this problem, simply by taking the announcement of the obligation of zakat that exists in the Qur'an - hadith.

From the above explanations are the constraints in reality faced in the management of zakat, which also influence the maximum collection of zakat funds in society and offices and companies. These factors affect the management of zakat management by the zakat institutions in Medan city, especially to the zakat collection and distribution sector. A small amount of zakat funding affects the small amount of zakat property distributed to the poor.

Nevertheless, zakat institutions in the city of Medan, never know the word surrender to manage zakat. The existing zakat institutions continue to improve their performance in various ways and strategies, ranging from internal improvements, good administrative, measurable financial statements to the promotion of socialization and cooperation, with the objective of zakat potential that must be extracted optimally in order to help the poor requiring.

\section{CONCLUSSION}

It cannot be denied that zakat is very potential as an effective means to empower the people's economy. The potential that when extracted optimally from the entire Islamic community and managed properly with the management of trust and high professionalism, will realize a large amount of funds that can be utilized to overcome poverty and empower the people's economy.

Zakat Profession is very wide scope it is very potential and functional to overcome the problem of poverty, which is currently, become an important agenda of economic development of Indonesia. The amount of poverty swelled from 22.5 million a year before the monetary crisis to nearly 100 million is a worrying reality. Therefore, the birth of Zakat Law in this reformation era is the right moment. Islamic teachings described in fiqih see there are three factors that determine the poorness of a person, first, property owned legally / halal and are in place. Second, a permanent livelihood justified by law. Based on the above indicator, those classified as poor are those who own property or permanent livelihood, but the results are not sufficient for basic needs. 
Zakat is the axis and financial center of an Islamic state. Zakat covers the moral, social, and economic fields. In the field of moral zakat erodes the greed and greed of the rich. In the social field, zakat acts as a typical tool given by Islam to eradicate the poverty of the people by awakening their social responsibilities. In the field of zakat economy prevents the accumulation of terrible wealth in the hands of a few people and allows wealth to be propagated before it could become big and very dangerous in the hands of its owners. It is the obligatory contribution of the Muslims to the State treasury.

\section{Refference}

Kahf, Monzer. 1989. Zakat: Unresolved Issues in the Contemporary Fiqh. Journal of Islamic Economics, 2 (1), pp. 122.

Firdaus, Muhammad, et al. 2012. Economic Estimation and Determinations of Zakat Potential in Indonesia, Working Paper Series WP\# 1433-140, Jeddah: IRTI-IDB.

Ahmed, H. 2004. The Role of Zakah and Awqaf in Poverty Alleviation. Islamic Research and Training Institute. Occasional Paper No.8. Jeddah: Saudi Arabia.

Ahmad, Juwaini, 2008. Zakat Management in Indonesian And Zakat Global Synergy, Paper for International Zakat Executive Development Programme, in Malaysia, 15-26 December 2008.

Beik, I.S. et al. 2011. Indonesia Zakat and Development Report 2011. Ciputat: IMZ.

El-Din, S.I.T. 1986. Allocative and Stabilizing Functions of Zakat in an Economy. Journal of Islamic Banking and Finance, 3:4

Pramanik, A. H. 1993. Development and Distribution in Islam. Pelanduk Publications, Petaling Jaya.

Jehle, G.A. 1994. Zakat and Inequality: Some Evidence from Pakistan. Review of Income and Wealth, Series 40:2, June.

Mintarti, N. et al. 2012. Indonesia Zakat and Development Report 2012. Ciputat : IMZ.

Patmawati, 2006, Economic Role of Zakat in Reducing Income Inequality and Poverty in Selangor. PhD Dissertation. Selangor: Universiti Putra Malaya.

Shirazi, Nasim Shah. 2006. Providing for the Resource Shortfall for Poverty Elimination Through the Institution of Zakat in Low-Income Muslim Countries. IIUM Journal of Economics and Management, 14 (1): 1-28.

Kahf, Monzer. 1989. Zakat: Unresolved Issues in the Contemporary Fiqh. Journal of Islamic Economics, 2 (1), pp. $1-22$. 